\title{
Journal of Biomedicine and Biotechnology
}

\author{
Jean Dausset
}

Pourquoi un nouveau journal médical? Pourquoi spécialement ce nouveau journal? Quelles sont ses ambitions? Quel public peut-il toucher? Des spécialistes, des généralistes ou les deux à la fois?

Il se veut être un lien entre la communauté scientifique internationale, plus particulièrement dans les domaines de la science du vivant et leur application technologique.

Il y a incontestablement un espace à occuper, un rôle important à jouer pour unir d'avantage cette communauté. Je me réjouis de l'initiative prise par ses promoteurs, qui ont eu le courage d'aborder une concurrence bien établie et à se lancer dans une aventure intellectuelle exaltante.

Pour ma part, je me permettrai d'aborder en quelques lignes quelques aspects qui me sont chers et qui sont suffisamment généraux pour faire l'objet d'un éditorial.

Où va en effet la médecine et que nous réserve la médecine de demain? Les progrès fantastiques dont nous avons été témoins, éblouis, entrent progressivement dans la pratique courante. La révolution à laquelle nous avons assisté se nomme, en particulier: la vaccination après Pasteur, qui a encore de beaux jours et de nouvelles perspectives (n'y-a-t'il pas de vaccin encore contre le paludisme ni contre le SIDA!), plus près de nous l'antibiothérapie, en plein essor mais qui commence à s'essouffler, à montrer ses limites du fait du développement rapide des résistances aux microorganismes. Ce n'est que depuis quelques décennies que la chirurgie immunologique a permis la transplantation d'organes ou de moelle osseuse, transplantation vieux rêve de l'humanité enfin réalisé et dont les succès eux-même entraînent, du fait de la pénurie des organes à transplanter, des déceptions parmi les très nombreux malades inscrits sur la liste d'attente. N'est-il pas admirable que, dans le monde entier, 6 millions d'individus sont prêts à donner leur moelle pour sauver des malades, en particulier leucémiques. A cette liste, devraiton ajouter les nombreuses victoires en cancérologie dues à un meilleur monitoring des agents antitumoraux? Et enfin, ne pas oublier les méthodes d'investigation biologique ou d'images médicales, qui se sont profondément améliorées récemment.

Ce panorama serait bien incomplet si je n'y ajoutais pas l'intrusion spectaculaire de la génétique médicale, qui permet de localiser, d'isoler les gènes de nombreuses maladies monogéniques et bientôt la gamme des gènes agissant de con- cert dans les maladies polygéniques, qui sont le lot désolant de nos sociétés industrialisées.

Muni de tout cet arsenal, le médecin, qu’il soit spécialiste ou généraliste, peut désormais proposer à ses malades des thérapeutiques de plus en plus efficaces, aboutissant souvent à la guérison ou à la chronicité. L'espoir de vie s'allonge chaque année, dans les pays industrialisés. Il faut qu'il en soit de même ailleurs.

J'ai lancé, il y a bien des années, le concept de médecine prédictive qui est basé sur les associations fréquentes entre certaines maladies et des allèles des gènes du système HLA. Par exemple, la spondylarthrite ankylosante associée à HLA-B27 ou le diabète insulino-dépendant associé à HLADR3, DR4. Ce concept est maintenant étendu à l'ensemble du génome humain et le nombre de gènes de susceptibilité (ou de protection) à de nombreuses maladies ne font que s'accroître. En dehors du système HLA, on connaît la susceptibilité au cancer du sein familial donné par des gènes tels que $\mathrm{BRC} 1$ et $\mathrm{BRC} 2$. Cette notion ne fait que s'étendre. Mais attention! Il ne peut être question de dépister les gènes de susceptibilité s'il n'y a pas, je dirai à la clé, une contrepartie préventive ou thérapeutique. On ne doit, en aucun cas, alerter une personne saine d'un avenir incertain, car il ne s'agit ici, je le souligne, que d'une probabilité d'un risque dont on peut connaître l'importance, sans en échange la proposition de moyens de prévention ou de traitement. Il serait inadmissible d'entraîner des angoisses inutiles.

Quoiqu'il en soit, la ligne est maintenant franchement tracée. Il y a de plus en plus de spécialités où des tests de présomption existent, qui doivent être mis au service du malade et non pas à son détriment.

Le médecin du XXI ${ }^{e}$ siècle, s'il applique avec prudence ces nouvelles notions, pourrait devenir le conseiller de ses clients saints, qui ne sont plus des malades. Chacun pourra alors gérer son capital-santé, comme on gère son capital bancaire, en toute connaissance de cause aidé par son médecin, averti des problèmes que pose la génétique.

N'est-il pas intéressant de constater que la médecine a été dans l'histoire tout d'abord curatrice, puis préventive et enfin prédictive, alors qu'aujourd'hui elle est dans l'ordre inverse: d'abord prédictive, puis préventive et enfin seulement, en désespoir de cause, curatrice. 


\section{PROFESSOR JEAN DAUSSET'S EDITORIAL IN ENGLISH}

Why a new medical journal? Why especially this new journal? What are its ambitions? What audience can it reach? Specialists, generalists or both simultaneously? It is intended to be a link between the international scientific community, in particular within the fields of life science and its technological application.

There is undoubtedly a niche to be occupied, an important role to be played to better link this community. I am delighted by the initiative taken by the promoters of this journal, who had the courage to enter the competitive field of scientific journals and to launch an exciting intellectual adventure.

For my part, I would like to briefly broach some medical questions that are dear to me, and that are sufficiently general to be the subject of an editorial.

Where indeed is medical practice going and what does the medicine of tomorrow hold for us? We have watched, amazed, the fantastic advances that are progressively entering current medical practice. The revolution we have witnessed has names, in particular: vaccination, developed by Pasteur, which still has new fields to conquer (until now there is no vaccine against malaria or against AIDS!). There is also antibiotic therapy, exploited to full advantage but beginning to run out of steam, showing its limitations because of the rapid rise of resistant microorganisms. It is only a few decades since developments in immunology have allowed the transplantation of organs or bone marrow. Transplantation — an old dream of humanity finally realized-whose successes themselves have led to many disappointments among the very many patients on the waiting lists, because of the shortage of the organs to be transplanted. It is nevertheless admirable that, in the whole world, 6 million individuals are ready to give their marrow to save patients, in particular those with leukemia. To this list of successes we should add the many victories in oncology due to improved monitoring of tumorigenic agents? And finally, we must not forget the methods of biological investigation and medical imaging, which have seen great improvements recently.

This panorama would be quite incomplete if I did not add the spectacular rise of medical genetics, which makes it possible to locate and to clone the genes responsible for many monogenic diseases and, in the near future, the genes that act in concert to produce the many polygenic diseases that afflict our industrialized societies.
Provided with this arsenal, the doctor, who is a specialist or general practitioner, can from now on offer to his patients increasingly effective therapies, often leading to the cure or amelioration of chronic diseases. Longevity continues to increase each year in the industrialized countries. It should be the same everywhere.

I initiated, many years ago, the concept of predictive medicine, based on frequent associations between some diseases and the alleles of genes of the HLA system. For example ankylosing spondylitis, associated with HLA-B27, or insulin dependent diabetes, associated with HLA-DR3/DR4. This concept has now been extended to the entire human genome and the number of genes of susceptibility to (or protection from) many diseases can only increase. Apart from the HLA system, we know of susceptibility to familial breast cancer, given by genes such as BRCA1 and BRCA2. This idea can only grow in importance, but there is a danger. There can be no question of detection of susceptibility genes without simultaneous development of a preventive or therapeutic counterpart. We should not, under any circumstances, warn a healthy person of an uncertain future, because in this caseand I emphasize this point-we are dealing with a risk of uncertain proportions, without a corresponding method of prevention or cure. It would be unforgivable to cause useless anxiety.

Whatever reservations we might have, the future direction is now clear. There are more and more specialties where tests of increased susceptibility to disease exist. These must be used for the benefit of the patient and not to his detriment.

The physician of the 21st century, if he or she applies these new concepts with prudence, could become the adviser of healthy patients, who are no longer ill. Each person will be able to manage his health capital, as he manages his banking capital; with full knowledge, guided by his doctor, of the developments of modern genetics.

Is it not interesting to note that medicine was, in its history, first of all curative, then preventive and finally predictive, whereas today the order is reversed: initially predictive, then preventive and finally, only in desperation, curative?

$$
\begin{gathered}
\text { Professor Jean Dausset } \\
\text { Nobel Laureate }
\end{gathered}
$$

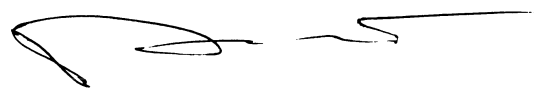



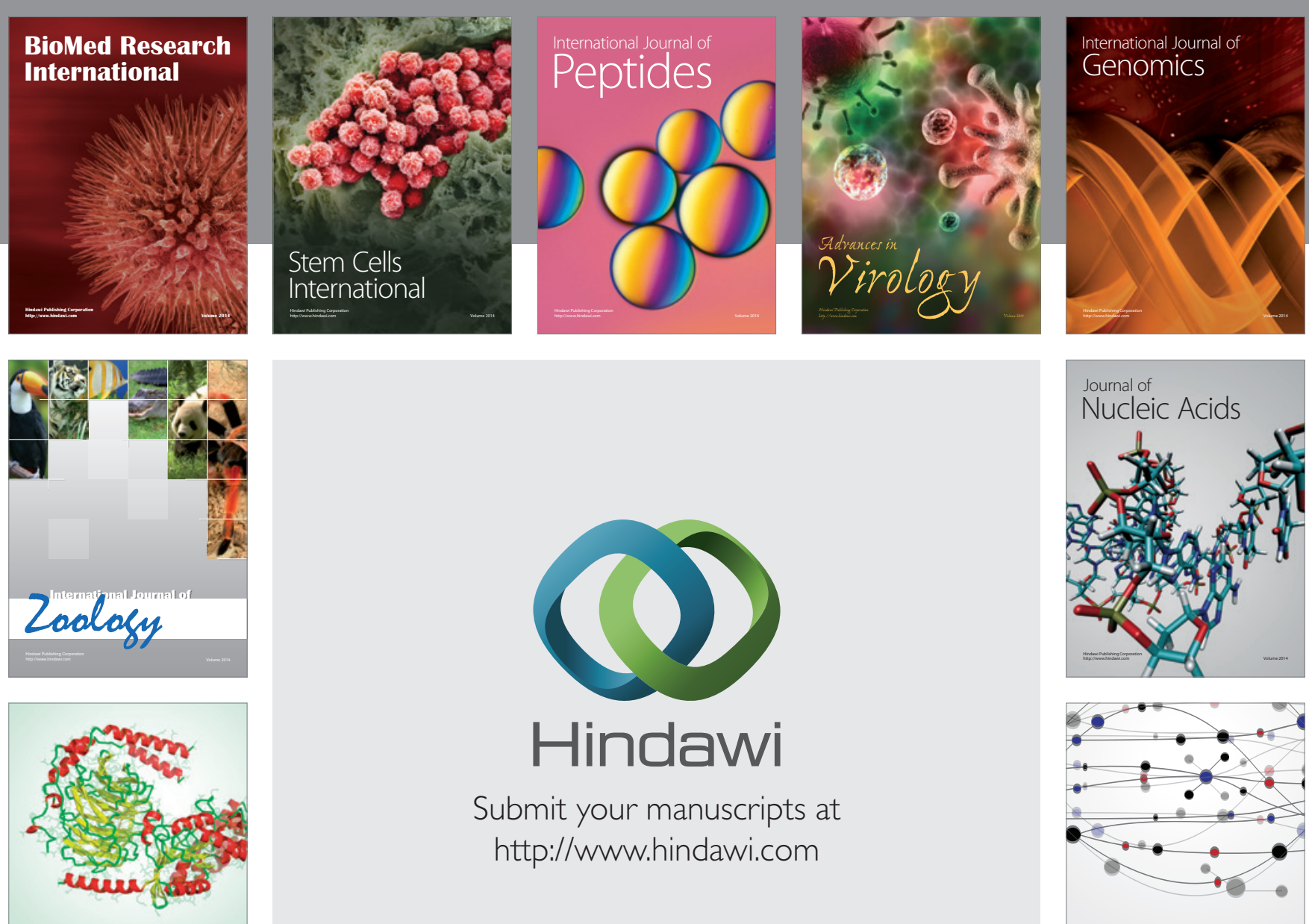

Submit your manuscripts at

http://www.hindawi.com

Signal ${ }^{\text {Jumal }}$ Transduction
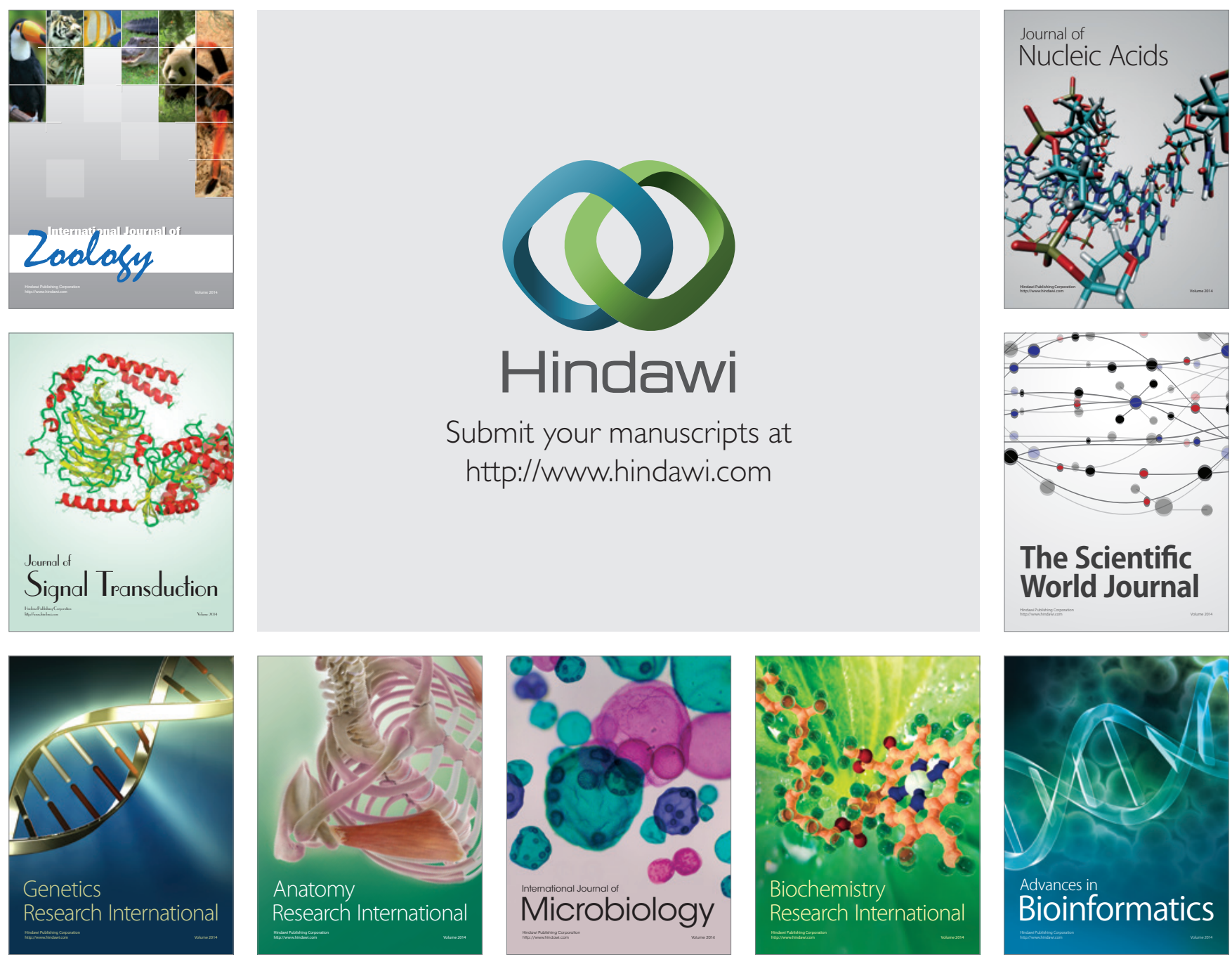

The Scientific World Journal
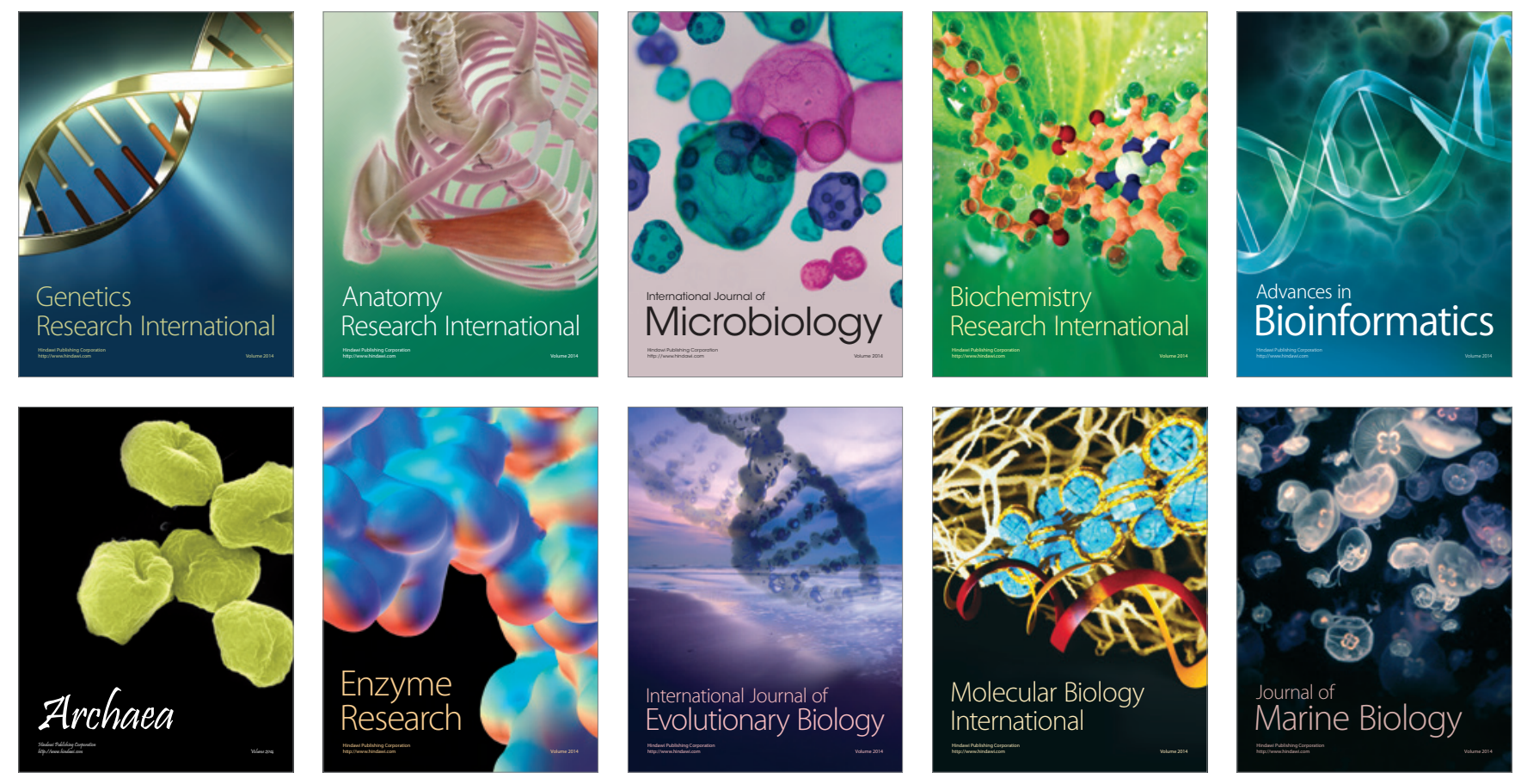